\title{
IS AUGMENTED REALITY THE NEW BLUE FOR PORT INDUSTRY?
}

\section{EBRU SÜRÜC $\ddot{U}^{1}$ and GÜL DENKTAŞ ŞAKAR ${ }^{2}$}

Key Words: Augmented Reality, blue ocean strategy, marketing strategy, seaports.

\section{INTRODUCTION}

In today's global world, firms notice the importance of designing and coordinating supply chains and distribution networks; while competing and surviving in harsh market conditions (Sengupta et al., 2006). To survive from intense competition, firms can choose blue ocean strategy. Blue ocean strategy mainly refers to creation of a new, uncontested market space -with the help of innovation- that makes competitors irrelevant and creates new customer value while generally decreasing costs (Kim and Mauborgne, 2005a). Ports must have a route that will differentiate themselves in order to adopt blue ocean strategy. Moreover, ports should use this tool in operations to differentiate themselves. One of the concepts that Industry 4.0 adds to our lives is Augmented Reality (AR) and it can act as a differentiating tool for port businesses in terms of services, processes, marketing communications, service delivery systems and pricing as well. The main aim of this paper is to provide an insight regarding the Augmented Reality concept in port business and discuss how such applications can serve in building blue ocean marketing strategies.

\section{LITERATURE REVIEW}

The discovery of new technologies has accompanied industry development from early adoption of mechanical systems to support production process, to today's highly automated assembly lines, in order to be responsive and adaptive current dynamic market requirements and demands (Lee et al. 2014). Ports as one of the main actors of service industry within the scope of maritime transport and logistics, need to meet the requirements of such changing environment by focusing on both the technological and service innovation. Since port activities are known

\footnotetext{
${ }^{1}$ Araş. Gör., Manisa Celal Bayar Üniversitesi, İşletme Fakültesi, Manisa ebru.surucu@cbu.edu.tr

2 Doç. Dr., Dokuz Eylül Üniversitesi, Denizcilik Fakültesi, İzmir gul.denktas@deu.edu.tr
} 
as complex in the supply chain activities, implementing new digital industrial technology will be useful which eventually lead to increased productivity in port activity and lead in change the profile of port workers (Popa et al. 2017). Main advance of new technologies will force the ports to be more technology-oriented and to be able to stay competitive and attract employees, even in the context of employee shortage. In the ports, innovations in equipment and information technologies are adapted to the port system to operate unmanned terminals based on automation, optimize operational processes to implement process innovations, and provide service innovations by providing integrated value-added logistics services as well as basic port services (Karataş Çetin and Sait, 2014). Moreover, literature review showed that studies related to port innovation has increased dramatically over the years (Blanco et al. 2010, Van den Bosch et al. 2011; Keçeli, 2011; Arduino et al. 2013; Cahoon et al. 2013; De Martino et al. 2013; Hall et al. 2013; Accaiaro et al. 2014; Karataş Çetin and Sait, 2014; Vanelslander et al. 2016; Quintana et al. 2016). Main port innovations can be grouped under eight groups as; port service innovations, process innovations, ecological innovations, information technologies innovations, social innovations, infrastructure innovations, organizational innovations and marketing innovations (Karataş Çetin and Sait, 2014).

Metaphor of "red oceans" and "blue oceans" represents the market universe. Red oceans are industries that exist today, in other words, the known market space. The Blue Ocean Strategy is "a consistent pattern of strategic thinking behind the creation of new markets and industries where demand is created rather than fought for and the rule of competition is irrelevant" (Kim and Mauborgne, 2005b). Blue oceans symbolize industries don't exist today (Kim and Mauborgne, 2005a). In blue oceans, demand is created instead of fighting for existing demand and blue oceans are areas free of competitors. They offer the possibility of profits and success and great customer satisfaction and thus create new demands by changing the basis of competition. To do so, they must be innovative and the heart of the Blue Ocean approach as in marketing and product development is customer knowledge. Thus, the key to avoiding disastrous competition is to leapfrog over the competition to serve customers in new ways (Chakrabarti, 2014).

\section{AUGMENTED REALITY IN THE PORT INDUSTRY}

Port industry has been hesitant to apply the AR applications. One of the reasons for such hesitation is that AR technology is generally not well understood in the industry and also there is a lack of application provider focusing on the specific uses of AR in the port industry. The main areas for gaining competitive advantage in the port industry are broadly 
categorized as: service-based, price-based, promotion-based, place-based reflections and lastly internal marketing reflections.

\section{Service-Based Reflections:}

Cargo Handling and Warehousing Services: Since ports' core business is basically focused on the cargo handling and warehousing of cargo for a certain period of time, any activity that can minimize the time spent and errors during operations can be considered as an efficient move for the port industry. AR technologies such as head-mounted display, cameras, a wearable PC and battery packs can provide energy for at least one work shift.

Terminal Area Planning and Port Expansion: In today's port environment, ports are not only considered as the nodes that provide handling services to the ships, but also, they house a growing number of value-added services such as packaging, repair, labeling, product assembly etc. AR can be used to visualize any planned rearrangements, making it possible to place interactive digital representations of proposed future modifications in the present.

Docking/Anchorage Services: Information about navigational dangers and presentation of data about other ships may be some other areas for $\mathrm{AR}$ in the port services.

Salvage and Repair Services: According to a project (US Navy's Divers Augmented Vision Display) conducted by US Navy, there is a highresolution, see-through head-up display embedded directly inside a diving helmet. AR delivers an image and outline of objects, overlaid on the actual diver's vision.

Geotagging: In Rushmore's (2016) article, few examples were provided in case of the use of AR in port service-related activities. In case of a need to check the hydraulic oil on a crane, the technician may not be experienced enough to know where to look for the particular crane and AR overlay can provide an exact location functioning as geotags in the ports.

Multimodal Operations: Transport industry makes extensive use of digital data and planning software for optimized load planning and vehicle utilization (DHL, 2014). In the multimodal operations of the ports, the transfer of containers from the terminal area to the trucks or trains or vice versa requires the detailed check of information regarding content, weight, size, destination, etc. 
Port Operations Control: AR applications are provided to offer various solutions to the operators at the port. In the control of the operations conducted at the port, AR can act as the main player in the minimization of the errors as well.

Safety and Security: In the field of safety and security, there might be huge fire and emergency personnel could have their vision blocked; an AR overlay may allow the emergency services to get to assets to shut down the equipment. (Rushmore, 2016).

\section{Price-Based Reflections:}

According to an expert, Cliffton Dawson, in a virtual/augmented reality analytical research firm in San Francisco, "ports need to consider the cost versus revenue balance before integrating AR to their systems. Although the cost of introducing $A R$ is decreasing dramatically, it may not be worth in some industries such as basic/low cost product assembly which may be the case of small ports". (Rushmore, 2016). However, big ports especially in container business, can generate new ways of differentiation through the application of AR Technologies.

\section{Promotion-Based Reflections}

HPA has established collaborative projects with the students at the University of Hamburg, where students are researching and developing apps for daily use at port operations through the use of AR (Port technology, 2016). Nowadays many companies use AR in their catalogs and brochures to achieve a fun gaming experience and introduce their products and services in a better way.

\section{Place-Based Reflections}

In the port marketing literature, place is discussed from various viewpoints in defining the marketing mix of the seaports. Branch (1998) defines "distribution" as being the marketing environment of the seaport where the sale is conducted. On the other hand, Frankel (1987: 604) argues that distribution refers to the delivery system alongside, sea island, topping off operations, lightering transshipment and impact of technological changes on infrastructure. AR applications can be used especially in the information-based service exchanges. Freight forwarders mostly prefer to be closer to the port information system in order to monitor the latest changes at the terminal regarding their customers' cargo movements. 


\section{Internal Marketing Reflections}

Use of AR can bring out valuable outcomes in terms of internal marketing activities. As Rob Smith from The Houston Consulting Group mentioned, AR Technologies can open up opportunities for job planning and job safety analysis. People can review the job and the specific areas of a port that they will be in, the location of the equipment and the possible dangers around the equipment such as crane movements. Crane operators may familiarize themselves with the environment that they were going to be working before the actual operation starts. This allows for a thorough safety review and a better-trained crane operator (Rushmore, 2016).

\section{CONCLUSION}

Since the aim of this paper is to provide an insight regarding the Augmented Reality concept in port business and discuss how such applications can serve in building blue ocean marketing strategies, an initial perspective on how Augmented Reality will help ports during the blue ocean marketing strategy creating process is provided with the literature review. As a future research idea, the framework created for this study can be improved by port specialist via focus group or face-to-face interviews. In the following years, as the AR applications become widespread in ports, the study can be expanded to cover more sophisticated uses of AR. Another research can be conducted with terminal operators, port users and customers about the AR and its possible usage areas in ports. Last but not least, the same framework can be applied different industries of the shipping industry as well. 